\title{
Oxidation of $\mathrm{TaSi}_{2}$-Containing $\mathrm{ZrB}_{2}$-SiC Ultra-High Temperature Materials
}

\author{
Elizabeth J. Opila, ${ }^{*}$, Jim Smith, Stanley R. Levine ${ }^{1,2}$, Jonathan Lorincz ${ }^{3}$ and Marissa Reigel ${ }^{4}$ \\ ${ }^{1}$ NASA Glenn Research Center, Cleveland, Ohio, OH 44135, USA \\ ${ }^{2}$ Retired \\ ${ }^{3}$ CONTECH Construction Products Inc., Englewood, CO 80111, USA \\ ${ }^{4}$ Savannah River Nuclear Solutions, Aiken, SC 29803, USA
}

\begin{abstract}
Hot pressed coupons of composition $\mathrm{ZrB}_{2}-20 \mathrm{v} \% \mathrm{SiC}-5 \mathrm{v} \% \mathrm{TaSi}_{2}$ and $\mathrm{ZrB}_{2}-20 \mathrm{v} \% \mathrm{SiC}-20 \mathrm{v} \% \mathrm{TaSi}{ }_{2}$ were oxidized in stagnant air at temperatures of 1627 and $1927^{\circ} \mathrm{C}$ for one, five and ten 10 -minute cycles. The oxidation reactions were characterized by weight change kinetics, $x$-ray diffraction, and SEM/EDS. Detailed WDS/microprobe quantitative analyses of the oxidation products were conducted for the $\mathrm{ZrB}_{2}-20 \mathrm{v} \% \mathrm{SiC}-20 \mathrm{v} \% \mathrm{TaSi} \mathrm{i}_{2}$ sample oxidized for five 10 -minute cycles at $1927^{\circ} \mathrm{C}$. Oxidation kinetics and product formation were compared to $\mathrm{ZrB}_{2}-20 \mathrm{v} \% \mathrm{SiC}$ with no $\mathrm{TaSi}_{2}$ additions. It was found that the $20 \mathrm{v} \% \mathrm{TaSi}_{2}$ composition exhibited improved oxidation resistance relative to the material with no $\mathrm{TaSi}_{2}$ additions at $1627^{\circ} \mathrm{C}$. However, for exposures at $1927^{\circ} \mathrm{C}$ less oxidation resistance and extensive liquid phase formation were observed compared to the material with no $\mathrm{TaSi}_{2}$ additions. Attempts to limit the liquid phase formation by reducing the $\mathrm{TaSi}_{2}$ content to $5 \mathrm{v} \%$ were unsuccessful. In addition, the enhanced oxidation resistance at $1627^{\circ} \mathrm{C}$ due to $20 \mathrm{v} \% \mathrm{TaSi}_{2}$ additions was not achieved at the $5 \mathrm{v} \%$ addition level. The observed oxidation product evolution is discussed in terms of thermodynamics and phase equilibria for the $\mathrm{TaSi}_{2}$-containing $\mathrm{ZrB}_{2}$-SiC material system. TaSi $i_{2}$-additions to $\mathrm{ZrB}_{2}-\mathrm{SiC}$ at any level are not recommended for ultra-high temperature $\left(>1900^{\circ} \mathrm{C}\right)$ applications due to excessive liquid phase formation.
\end{abstract}

Keywords: $\mathrm{ZrB}_{2}, \mathrm{SiC}, \mathrm{TaSi}_{2}$, Oxidation kinetics, Furnace testing, Microstructural characterization.

\section{INTRODUCTION}

$\mathrm{ZrB}_{2}$ and related materials are considered for ultra-high temperature applications such as leading edges of hypersonic vehicles due to their high melting points. However, application of these materials is limited due to their poor oxidation resistance, low toughness, and low thermal shock resistance [1]. This paper addresses methods to improve the oxidation resistance of $\mathrm{ZrB}_{2}$. $\mathrm{ZrB}_{2}$ oxidizes to form $\mathrm{B}_{2} \mathrm{O}_{3}$ and $\mathrm{ZrO}_{2}$. At temperatures between 450 and about $1100^{\circ} \mathrm{C}$, liquid phase boria is formed [2]. This liquid phase provides a somewhat protective liquid layer that slows oxygen transport to the underlying substrate. At temperatures greater than $1100^{\circ} \mathrm{C}$, the $\mathrm{B}_{2} \mathrm{O}_{3}$ boils off allowing rapid transport of oxygen through the zirconia scale to the underlying $\mathrm{ZrB}_{2}$ substrate. Additions of $20 \mathrm{v} \% \mathrm{SiC}$ to $\mathrm{ZrB}_{2}$ [3] provided improved oxidation resistance since the formation of a silica scale provides protection to much higher temperatures dependent on the amount of additive and oxidation condition [4]. However, at temperatures above the melting point of silica $\left(\mathrm{T}_{\mathrm{m}}=1723^{\circ} \mathrm{C}\right.$ [5]), the liquid film can be lost to volatility and shear forces in high velocity applications [6]. Many studies have been conducted to add additional constituents to the $\mathrm{ZrB}_{2}-\mathrm{SiC}$ system in attempts to further increase the oxidation resistance. $\mathrm{TaSi}_{2}$ is one such constituent that has been considered to increase the oxidation resistance.

*Address correspondence to this author at the NASA Glenn Research Center, Cleveland, Ohio, OH 44135, USA; Tel: 001 216-433-8904; Fax: 001 216-433-5544; E-mail: opila@nasa.gov
It has been demonstrated that $\mathrm{Ta}$ additions to $\mathrm{ZrB}_{2}$-based materials showed improved oxidation resistance relative to the baseline materials at moderately high temperatures $\left(\mathrm{T} \leq 1627^{\circ} \mathrm{C}\right)$. Talmy et al. showed that two to twenty mol\% $\mathrm{TaB}_{2}$ additions to $\mathrm{ZrB}_{2}-\mathrm{SiC}$ resulted in improved oxidation resistance at temperatures between 1200 and $1400^{\circ} \mathrm{C}$ [7]. Similarly, $\mathrm{Ta}_{5} \mathrm{Si}_{3}$ and $\mathrm{TaSi}_{2}$ additions in the amounts of 8-31 $\mathrm{v} \%$ showed improved oxidation resistance relative to $\mathrm{ZrB}_{2}$ at temperatures between 1100 and $1400^{\circ} \mathrm{C}$ in air for times of two to three hours $[8,9]$. In all cases, Talmy showed evidence for immiscible glass formation in the oxidation products and attributed the improved oxidation resistance to the steeply rising liquidus temperatures, increased viscosity, and decreased oxygen diffusivity [7] of the phase-separated glasses. Opila et al. [10] showed that $\mathrm{ZrB}_{2}-20 \mathrm{v} \% \mathrm{SiC}-20$ $\mathrm{v} \% \mathrm{TaSi}_{2}$ resulted in a ten-fold reduction in oxide thickness relative to $\mathrm{ZrB}_{2}-20 \mathrm{v} \% \mathrm{SiC}$ after oxidation at $1627^{\circ} \mathrm{C}$ for 100 minutes in stagnant air. This improvement was attributed to the presence of $\mathrm{Ta}$ rather than the increased Sicontent. The mechanism for improved oxidation behavior was not determined, however, it was proposed that this result was either due to formation of immiscible glass phases or Ta-doping of the $\mathrm{ZrO}_{2}$ scale.

$\mathrm{TaSi}_{2}$ has a melting point of approximately $2200^{\circ} \mathrm{C}$ $[11,12]$ so the material itself has high temperature capability. The expected oxidation products, $\mathrm{SiO}_{2}$ and $\mathrm{Ta}_{2} \mathrm{O}_{5}$ have melting points of $1723^{\circ} \mathrm{C}[5]$ and $1872^{\circ} \mathrm{C}\left(\alpha-\mathrm{Ta}_{2} \mathrm{O}_{5}\right)$ [13] respectively. Upon oxidation at temperatures above $1872^{\circ} \mathrm{C}$, 
$\mathrm{TaSi}_{2}$ is therefore expected to form a liquid phase. For mixed $\mathrm{ZrB}_{2}-\mathrm{SiC}-\mathrm{TaSi}_{2}$, the oxidation products are expected to be more complex. The formation of $\mathrm{Ta}_{2} \mathrm{O}_{5}-\mathrm{xZrO}_{2}$ phase $\mathrm{V}$ with $x$ reportedly varying between 5 and 8 [14-16] is possible. The melting temperature of this phase is unknown, but has been reported to be $>1870^{\circ} \mathrm{C}$ [14]. Thus, this oxidation product is also likely to limit the temperature capability of $\mathrm{TaSi}_{2}$-containing $\mathrm{ZrB}_{2}$-SiC compositions. It was proposed [10] that additions of small amounts $(<20 \mathrm{v} \%)$ of $\mathrm{TaSi}_{2}$ to $\mathrm{ZrB}_{2}$ might result in oxidation to form $\mathrm{Ta}_{2} \mathrm{O}_{5}$ in solution with $\mathrm{ZrO}_{2}$, thus preventing formation of these low melting oxides. While the extent of $\mathrm{Ta}_{2} \mathrm{O}_{5}$ solubility is unknown, a phase diagram for the related $\mathrm{Nb}_{2} \mathrm{O}_{5}-\mathrm{ZrO}_{2}$ system shows 5 to 10 mol\% solubility of $\mathrm{Nb}_{2} \mathrm{O}_{5}$ in $\mathrm{ZrO}_{2}[16]$.

The objectives of this work are to: 1) Extend the previous work with $\mathrm{ZrB}_{2}-20 \mathrm{v} \% \mathrm{SiC}-20 \mathrm{v} \% \mathrm{TaSi}_{2}$ [10] to the lower $\mathrm{TaSi}_{2}$ level of $5 \mathrm{v} \%$ for developing enhanced oxidation resistance at both 1627 and $1927^{\circ} \mathrm{C}$, and 2) Interpret the results of a detailed characterization of $\mathrm{ZrB}_{2}-20$ $\mathrm{v} \% \mathrm{SiC}-20 \mathrm{v} \% \mathrm{TaSi}_{2}$ before and after oxidation using microprobe and quantitative WDS to understand liquid phase formation arising from $\mathrm{TaSi}_{2}$ additions, the whereabouts of the $\mathrm{Ta}$ in the oxide scale, and possible steps to mitigate liquid-phase formation.

\section{MATERIALS AND METHODOLOGY}

$\mathrm{ZrB}_{2}-\mathrm{SiC}-\mathrm{TaSi}_{2}$ coupons were prepared from powders described in Table 1. Processing history is summarized in Table 2. Several batches of the same composition were made. The powders were mixed, and then milled using $\mathrm{Si}_{3} \mathrm{~N}_{4}$ media in hexane in a $\mathrm{Si}_{3} \mathrm{~N}_{4}$ mill for $24 \mathrm{~h}$. The powders were vacuum hot pressed using a graphite die. Further details can be found in reference [17]. Sample coupons of $2.5 \mathrm{~cm} \times 1.2$ $\mathrm{cm} \times 0.3 \mathrm{~cm}$ were machined from hot pressed plates. The coupons were ultrasonically cleaned in detergent (Micro-90, International Products Corporation), de-ionized water, acetone, and alcohol prior to oxidation. X-ray diffraction and Energy Dispersive Spectroscopy of as-machined and cleaned coupons indicated $\mathrm{ZS} 20 \mathrm{TS}$ contained $\mathrm{ZrB}_{2}, \mathrm{SiC}, \mathrm{TaSi}_{2}$ and a minor amount of a $(\mathrm{Zr}, \mathrm{Ta})$ boride solution.

Table 1. Powders Used for Sample Preparation

\begin{tabular}{|c|c|c|c|}
\hline Material & Source & Particle Size & Purity\% \\
\hline \hline $\mathrm{ZrB}_{2}$ & Cerac & $<10 \mu \mathrm{m}$ & 99.5 \\
\hline $\mathrm{SiC}$ & HC Starck & $<5 \mu \mathrm{m}$ & $>99.9$ \\
\hline $\mathrm{TaSi}_{2}$ & Cerac & $80 \%-325$ mesh $(-44 \mu \mathrm{m})$ & $>99.9$ \\
\hline
\end{tabular}

Initial surface areas and sample weights were recorded. The samples were oxidized at $1627^{\circ} \mathrm{C}$ in stagnant air in a bottom loading CM Inc. $\mathrm{MoSi}_{2}$ element box furnace. The samples were oxidized at $1927^{\circ} \mathrm{C}$ in stagnant air in a bottom loading DelTech, Inc. zirconia element furnace. Three coupons were loaded into a slotted calcia-stabilized zirconia firebrick setter ( $98.7 \%$ purity). Two lines of contact existed between the setter and sample. The coupons were oxidized for ten minute cycles. On heat-up to $1627^{\circ} \mathrm{C}$, the furnace temperature reached approximately 100 degrees less than the set temperature in 1 minute. Heating to the set temperature was complete 5 minutes into the heating cycle. The DelTech furnace temperature fell by approximately 75 degrees during the loading process. Samples were removed from the furnace and cooled in ambient conditions for 10 minutes between cycles. A coupon was removed after one cycle, five cycles, and ten cycles. A maximum oxidation time of 100 minutes was achieved. Post-oxidation weight changes were recorded where possible. Some coupons stuck to the zirconia setter due to extensive glass formation.

Optical macrographs were taken of all coupons after oxidation. The sample surfaces were analyzed by X-Ray Diffraction (XRD), Field Emission Scanning Electron Microscopy (FESEM) Hitachi S-4700, and Energy Dispersive Spectroscopy (EDS) to determine phases present before and after oxidation as well as oxide microstructures. Several materials were also examined by FESEM and EDS in cross-section prepared by non-aqueous cutting and polishing procedures to preserve boria-containing phases. The ZSTS20 coupon previously oxidized for five cycles (50 minutes total exposure) at $1927^{\circ} \mathrm{C}$ was also characterized extensively by Wavelength Dispersive Spectroscopy (WDS) microprobe (JEOL 8200). Each reported phase composition determined by microprobe is the average of five measurements.

\section{RESULTS}

\section{Oxidation Kinetics}

The weight change results for ZS, ZSTS5, and ZSTS20 obtained at $1627^{\circ} \mathrm{C}$ in stagnant air are shown in Fig. (1). Macrophotos of the materials after oxidation at $1627^{\circ} \mathrm{C}$ are shown in Fig. (2). Surface SEM images are shown in Fig. (3) for all three compositions while cross sections of the oxide scale are shown in Fig. (4). XRD results for all the oxidized materials were similar and showed only $\mathrm{ZrO}_{2}$ (monoclinic) with minor amounts of $\mathrm{ZrO}_{2}$ (cubic). No additional phases were observed. Macrographs of ZS, ZSTS5, and ZSTS20

Table 2. Summary of Compositions, Designations, and Processing

\begin{tabular}{|c|c|c|c|c|}
\hline Composition & Designation/Oxidation Temperature $\left({ }^{\circ} \mathrm{C}\right)$ & Processing & Density, $\mathbf{g} / \mathrm{cm}^{3}$ & Relative Density, \% \\
\hline $\mathrm{ZrB}_{2}-20 \mathrm{v} \% \mathrm{SiC}$ & $\mathrm{ZS}$ & $2000^{\circ} \mathrm{C}, 10 \mathrm{ksi}, 2 \mathrm{~h}$ & 5.27 & 95.5 \\
\hline $\mathrm{ZrB}_{2}-20 \mathrm{v} \% \mathrm{SiC}-20 \mathrm{v} \% \mathrm{TaSi}_{2}$ & ZSTS20-1927 & $1600^{\circ} \mathrm{C}, 10 \mathrm{ksi}, 2 \mathrm{~h}$ & 6.04 & 99.7 \\
\hline $\mathrm{ZrB}_{2}-20 \mathrm{v} \% \mathrm{SiC}-5 \mathrm{v} \% \mathrm{TaSi}_{2}$ & ZSTS5-1627 & $1750^{\circ} \mathrm{C}, 10 \mathrm{ksi}, 2 \mathrm{~h}$ & 5.52 & 97.6 \\
\hline
\end{tabular}


after oxidation at $1927^{\circ} \mathrm{C}$ are shown in Fig. (5). The results for ZS and ZSTS20 were previously published [10] but are shown here for comparison.

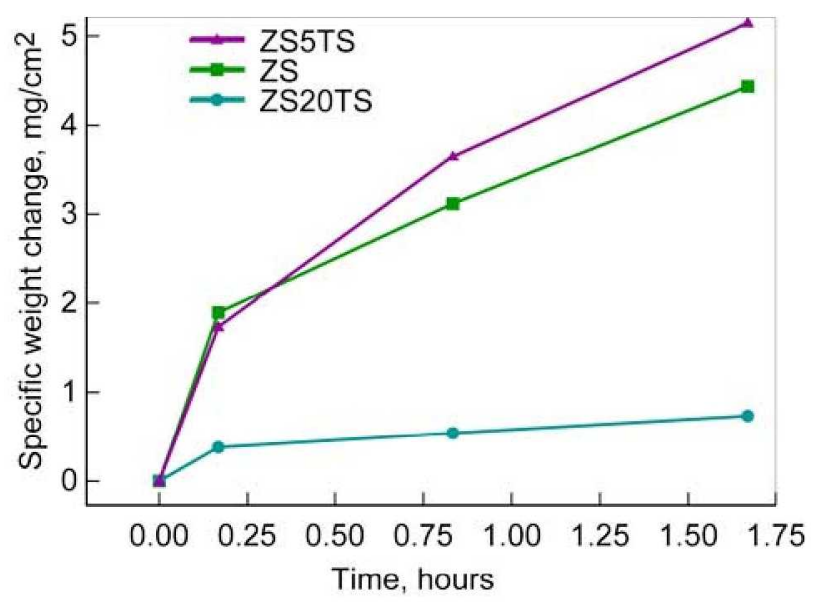

Fig. (1). Weight change results obtained at $1627^{\circ} \mathrm{C}$ in stagnant air for $\mathrm{ZrB}_{2}-20 \mathrm{v} \% \mathrm{SiC}$ baseline material compared to compositions containing 5 and $20 \mathrm{v} \% \mathrm{TaSi}_{2}$. ZS and ZS20TS from ref. [9].

The weight change results and macrophotos for the sample exposed at $1627^{\circ} \mathrm{C}$ show that $\mathrm{ZrB}_{2}-20 \mathrm{v} \% \mathrm{SiC}-20$ $\mathrm{v} \% \mathrm{TaSi}_{2}$ shows the best oxidation behavior. The addition of $5 \mathrm{v} \% \mathrm{TaSi}_{2}$ to $\mathrm{ZrB}_{2}-20 \mathrm{v} \% \mathrm{SiC}$ is insufficient to lead to phase separation in the glass, whereas $20 \mathrm{v} \% \mathrm{TaSi}_{2}$ additions result in immiscible glass formation as shown in Fig. (3). The oxidation thickness is reduced approximately ten times for $20 \mathrm{v} \% \mathrm{TaSi}_{2}$ relative to the material with no additives as shown in Fig. (4) [10]. The oxide cross-section for the sample with $5 \mathrm{v} \% \mathrm{TaSi}_{2}$ is not shown since the scale was bubbled and varied irregularly in thickness between 4 and $100 \mu \mathrm{m}$ for a sampling of 20 locations. At $1927^{\circ} \mathrm{C}$, the material with no $\mathrm{TaSi}_{2}$ exhibits the best oxidation behavior since liquid phase formation is limited. Extensive liquid formation is observed for both the 5 and $20 \mathrm{v} \% \mathrm{TaSi}_{2}$ addition levels.

\section{Microstructural/Compositional Characterization of ZSTS20 Before and After $1927^{\circ} \mathrm{C}$ Exposure in Stagnant Air for 50 Minutes}

In previous work [10], EDS analysis of the ZSTS oxidation products was complicated by the fact that the $\mathrm{Ta}$ M $\alpha$ peak $(1.709 \mathrm{keV})$ has almost complete overlap with the $\mathrm{Si} \mathrm{K} \alpha$ peak $(1.739 \mathrm{keV})$. Ta identification was made primarily by observing the low intensity $\mathrm{Ta} L \alpha$ peak at 8.145
$\mathrm{keV}$. In addition, phases with high $\mathrm{Si}$ content had much darker contrast than those with high $\mathrm{Ta}$ content. Nevertheless, it was uncertain where Ta was incorporated into the oxidation products. In addition, the composition of the low melting phase was unknown, preventing an understanding of possible ways to improve the high temperature oxidation resistance of ZSTS materials. In this paper, microprobe wavelength dispersive spectroscopy (WDS) was used to more completely characterize the oxidation products. The following microprobe results are presented beginning with the substrate and proceeding outward through the layers of the oxide products formed to identify the key reactions occurring during the oxidation exposure at $1927^{\circ} \mathrm{C}$. Results are summarized in Table 3 .

\section{Substrate Before Oxidation}

After hot pressing, in addition to the starting phases $\mathrm{ZrB}_{2}$, $\mathrm{SiC}$, and $\mathrm{TaSi}_{2}$, an additional phase zirconium rich boride phase $(\mathrm{Zr}, \mathrm{Ta}) \mathrm{B}_{\mathrm{x}}$ was observed as shown in Fig. (6). This solution phase has been previously observed $[8,10]$ and is reasonable since both $\mathrm{ZrB}_{2}$ and $\mathrm{TaB}_{2}$ have a hexagonal crystal structure. XRD results showed that the (100), (101), and (111) peaks for $\mathrm{ZrB}_{2}$ all exhibited shoulders displaced by 0.1 to 0.5 degrees 2 theta higher indicating reduction of the lattice parameters of the hexagonal $\mathrm{ZrB}_{2}$ structure with the introduction of $\mathrm{TaB}_{2}$

\section{Substrate After Oxidation}

After oxidation, the $\mathrm{TaSi}_{2}$ is no longer found in the substrate throughout the entire thickness as shown in Fig. (6). Fig. (6b) was obtained near the center of the coupon. The $\mathrm{Ta}$ is now present as a carbide $(\mathrm{Ta}, \mathrm{Zr}) \mathrm{C}_{\mathrm{r}}$. The amount of $\mathrm{ZrB}_{2}$ and $\mathrm{SiC}$ have both decreased relative to the starting material whereas the amount of $(\mathrm{Zr}, \mathrm{Ta}) \mathrm{B}_{\mathrm{x}}$ phase has increased. Porosity is found throughout the substrate.

\section{Substrate Near Oxide Interface}

Fig. (7) shows elemental analysis at the substrate/oxide interface. Note that $\mathrm{ZrB}_{2}$ and $\mathrm{SiO}_{2}$ are present just below $\mathrm{ZrO}_{2}$-containing oxide scale in a very thin layer. Below this layer, all Si-containing phases are depleted for approximately $150 \mu \mathrm{m}$.

\section{Oxide Near Oxide Interface}

Figs. $(7,8)$ show that $\mathrm{Ta}$ is found near the $\mathrm{ZrB}_{2} / \mathrm{ZrO}_{2}$ interface in the small $(\sim 1 \mu \mathrm{m})$ grains of Ta oxyborides with brightest contrast. Large $\mathrm{ZrO}_{2}$ grains are observed in a sea of $\mathrm{SiO}_{2}$. Figs. $(7,8)$ also show that $\mathrm{Ta}$ and $\mathrm{B}$ are present at low levels throughout much of the oxide scale.

ZS: 1,5 , and 10 cycles ZS5TS: 1,5 , and 10 cycles ZS20TS: 1,5 , and 10 cycles

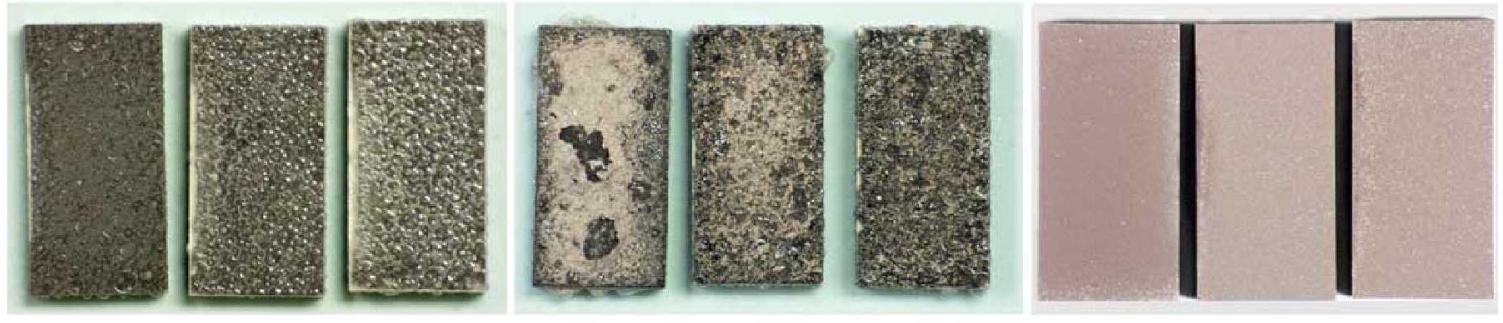

Fig. (2). Macrophotos of coupons after oxidation at $1627^{\circ} \mathrm{C}$ in stagnant air. 

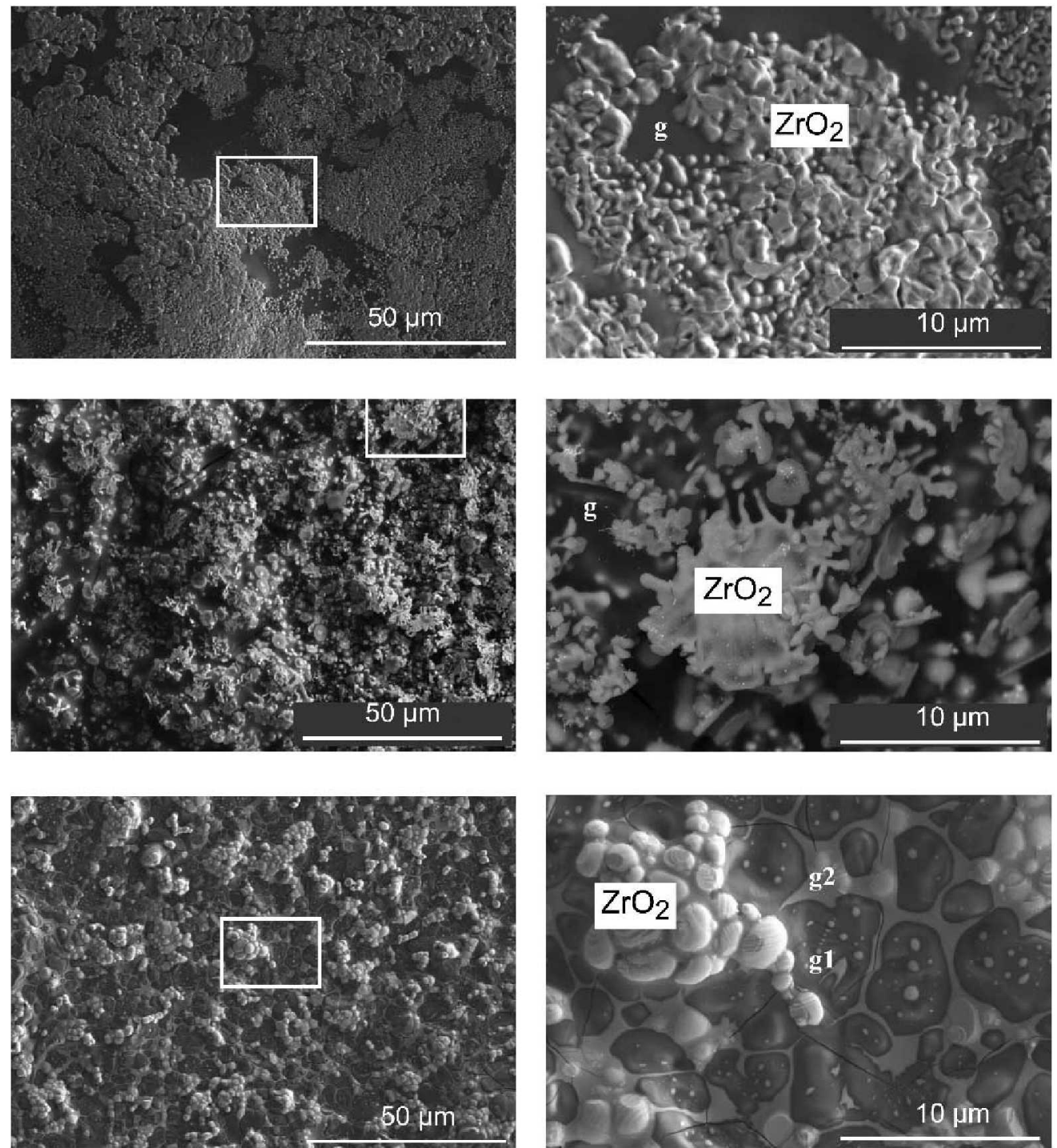

Fig. (3). Secondary electron images showing surface morphology of the ZS (top), ZSTS5 (middle), and ZSTS20 (bottom) after oxidation at $1627^{\circ} \mathrm{C}$ for $100 \mathrm{~min}$ in stagnant air. Details of area in white box on left are shown in higher magnification on the right. $\mathrm{ZrO}{ }_{2}$ and glass $(\mathrm{g}$ ) phases are labeled in the right hand micrographs. Note that only the ZSTS20 shows evidence of immiscible glass formation: g1 is silica rich while $\mathrm{g} 2$ contains $\mathrm{Al}$ and $\mathrm{Mg}$ impurities.
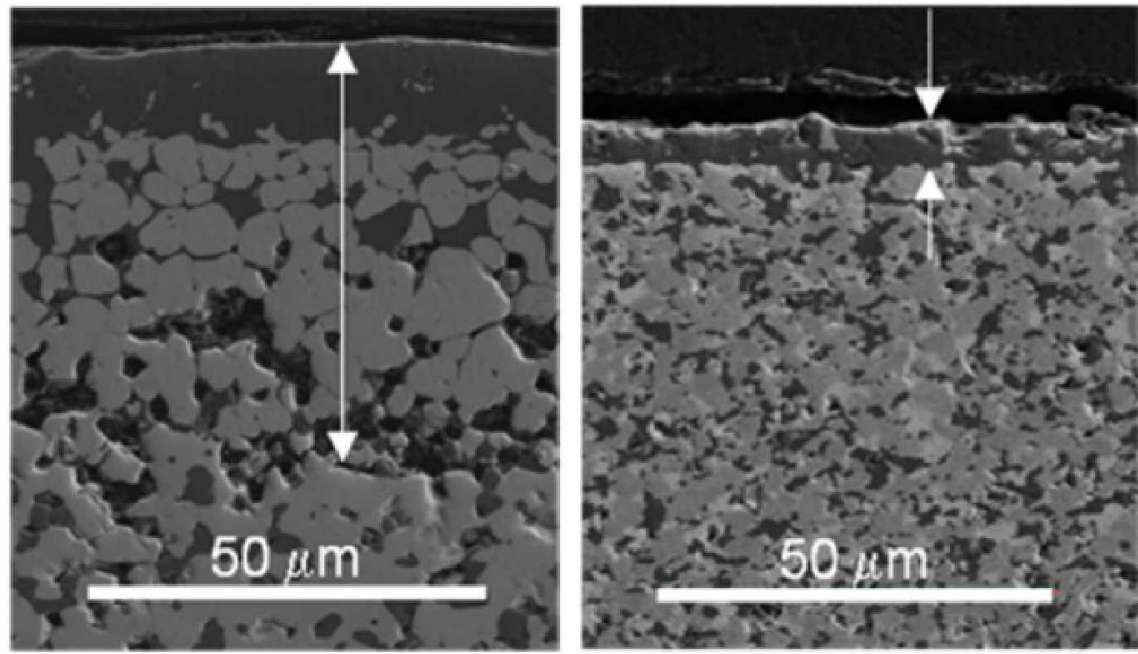

Fig. (4). Secondary electron images showing cross-sections of the ZS and ZSTS20 after oxidation at $1627^{\circ} \mathrm{C}$ for 100 min in stagnant air [10]. White arrows show the oxide thickness. 


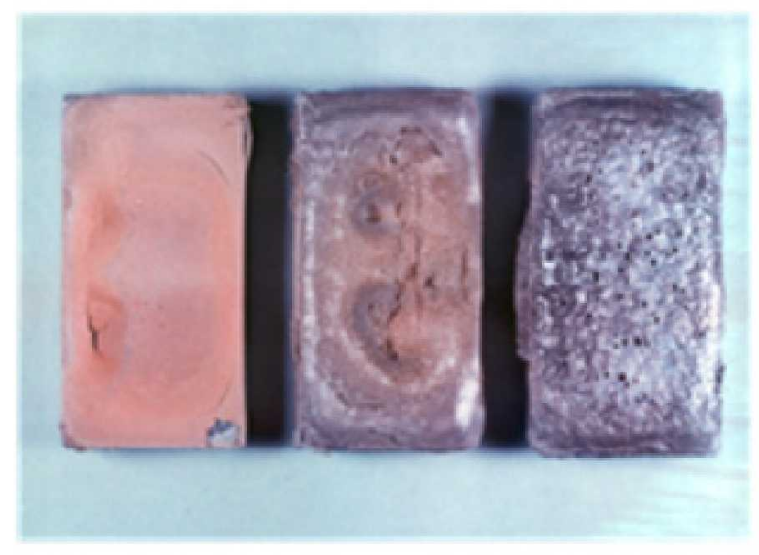

ZS: 1,5 , and 10 cycles

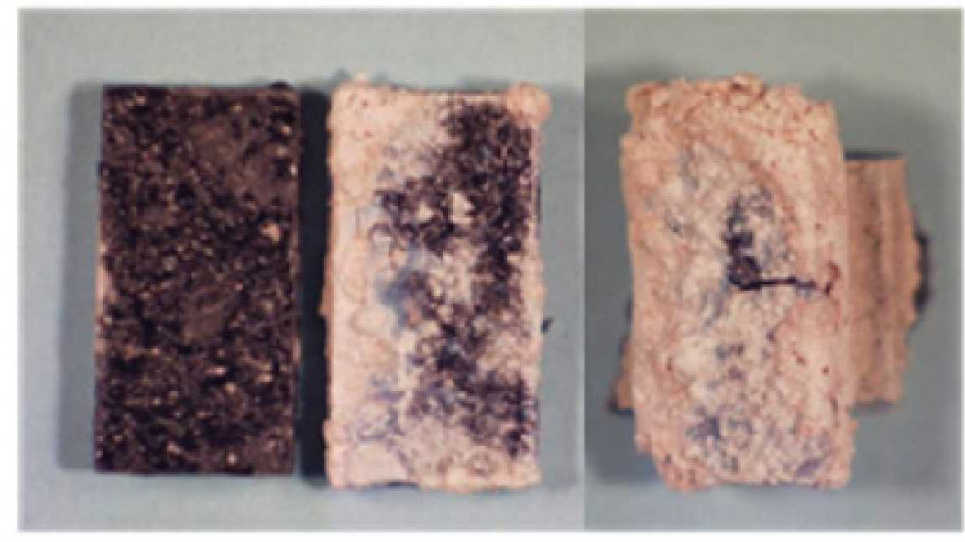

\section{ZSTS5: 1, 5, and 7 cycles}

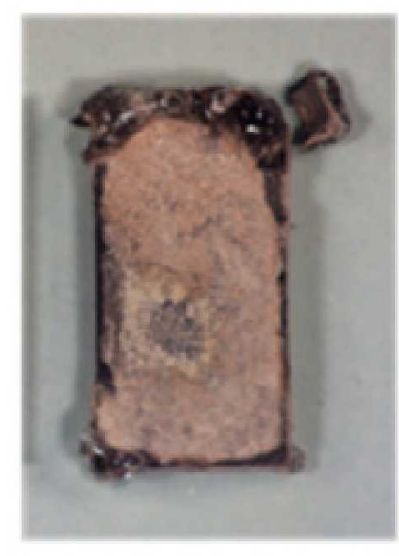

ZSTS20: 1 cycle
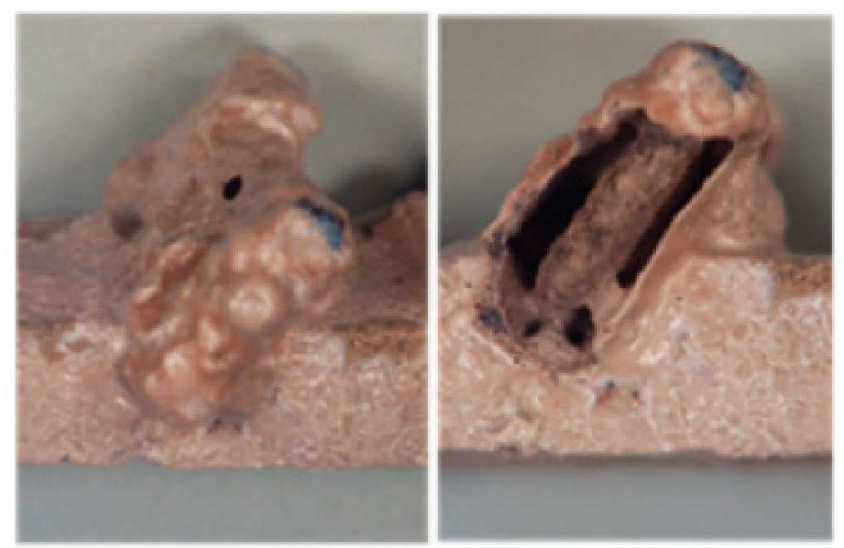

ZSTS20: 5 cycles

Fig. (5). Macrographs of ZS, ZSTS5, and ZSTS20 after oxidation at $1927^{\circ} \mathrm{C}$ for 10 minute cycles in stagnant air.

Table 3. Summary of Phases/Compositions Determined by WDS/Microprobe for ZSTS20 after Oxidation at $1927^{\circ} \mathrm{C}$ in Stagnant $^{-}$ Air for 5 ten-Minute Cycles

\begin{tabular}{|c|c|c|c|c|c|c|c|c|c|c|}
\hline Sample Location & $\mathbf{Z r B}_{2}$ & SiC & $\mathbf{T a S i}_{2}$ & $(\mathbf{Z r}, \mathbf{T a}) \mathbf{B}_{\mathbf{x}}$ & $(\mathbf{Z r}, \mathbf{T a}) \mathbf{C}_{\mathbf{x}}$ & $\begin{array}{c}\mathrm{ZrO}_{2} \\
\text { (at\% Ta) }\end{array}$ & $\begin{array}{c}\mathrm{SiO}_{\mathbf{x}} \\
(\mathrm{at} \% \mathrm{Ta})\end{array}$ & $\operatorname{Ta}(0, B)$. & $\mathrm{Ta}(\mathbf{C}, \mathbf{B})_{\mathbf{x}}$ & (Zr,Ta) $\mathbf{O}_{\mathbf{r}}$ \\
\hline $\begin{array}{l}\text { Substrate as hot- } \\
\text { pressed }\end{array}$ & $\checkmark$ & $\checkmark$ & $\checkmark$ & $\begin{array}{c}\checkmark \\
\mathrm{Zr} / \mathrm{Ta}=4.2 \\
\mathrm{x}=1.5\end{array}$ & & & & & & \\
\hline $\begin{array}{l}\text { Substrate after } \\
\text { oxidation }\end{array}$ & $\checkmark$ & $\checkmark$ & & $\begin{array}{c}\checkmark \\
\mathrm{Zr} / \mathrm{Ta}=3.5 \\
\mathrm{x}=1.4\end{array}$ & $\begin{array}{c}\checkmark \\
\mathrm{Zr} / \mathrm{Ta}=0.6 \\
\mathrm{x}=1.4\end{array}$ & & & & & \\
\hline $\begin{array}{l}\text { Substrate near } \\
\text { oxide interface }\end{array}$ & $\checkmark$ & & & & & & $\begin{array}{c}\checkmark \\
\mathrm{x}=2.0\end{array}$ & & & \\
\hline $\begin{array}{l}\text { Oxide near } \\
\text { interface }\end{array}$ & & & & & & $\begin{array}{c}\checkmark \\
(0.2)\end{array}$ & $\begin{array}{c}\checkmark \\
x=2.0 \\
(0.1)\end{array}$ & $\begin{array}{c}\checkmark \\
\mathrm{B} / \mathrm{O}=2.2 \\
\mathrm{x}=1.4\end{array}$ & & \\
\hline $\begin{array}{l}\text { Middle portion of } \\
\text { attached scale }\end{array}$ & & & & & & $\begin{array}{c}\checkmark \\
(0.5)\end{array}$ & $\begin{array}{c}\checkmark \\
x=2.4 \\
(1.6)\end{array}$ & $\begin{array}{c}\checkmark \\
\mathrm{B} / \mathrm{O}=1.7 \\
\mathrm{x}=0.7\end{array}$ & $\begin{array}{c}\checkmark \\
\mathrm{C} / \mathrm{B}=1.3 \\
\mathrm{x}=1.0\end{array}$ & \\
\hline $\begin{array}{l}\text { Outer surface, } \\
\text { detached scale }\end{array}$ & & & & & & $\begin{array}{c}\checkmark \\
(0.6,1.3) \\
2 \text { areas } \\
\text { analyzed }\end{array}$ & $\begin{array}{c}\checkmark \\
x=3.1 \\
(2.5)\end{array}$ & & & $\begin{array}{c}\checkmark \\
\mathrm{Z} \mathbf{r} / \mathrm{Ta}=1.9 \\
\mathrm{x}=2.5\end{array}$ \\
\hline
\end{tabular}



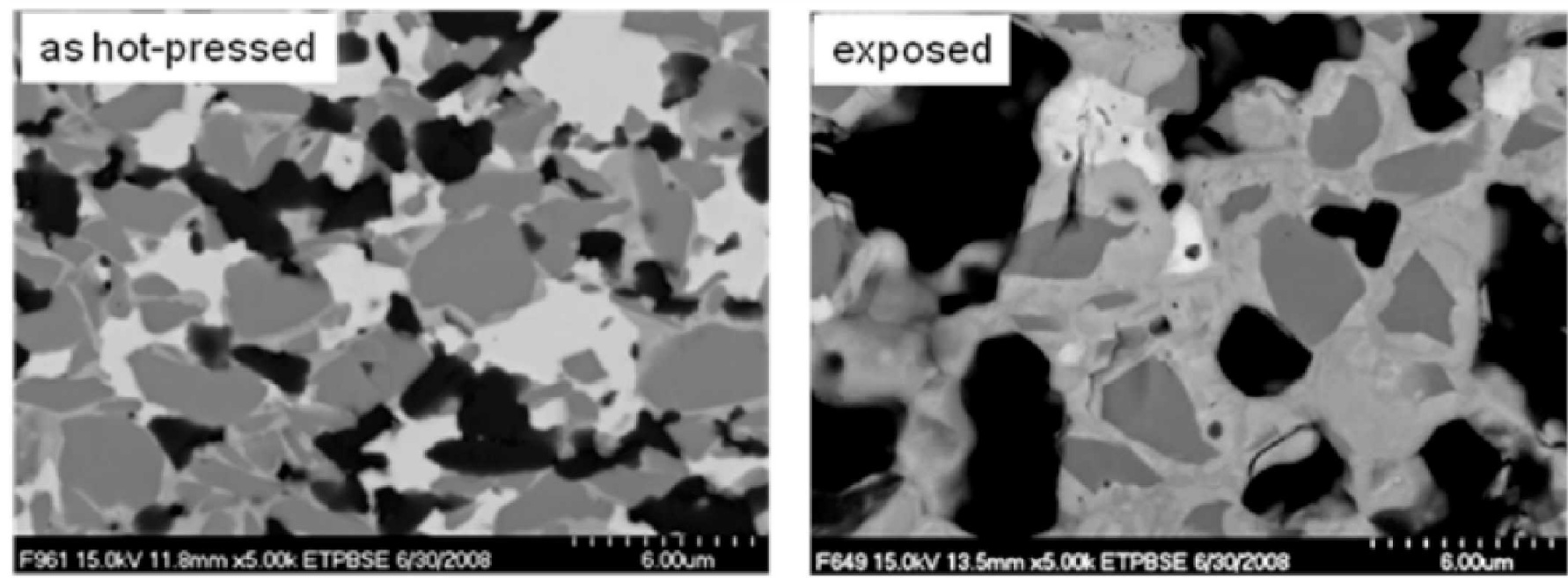

Fig. (6). Backscattered electron image of ZSTS20 substrate before and after oxidation for 50 min at $1927^{\circ} \mathrm{C}$ in stagnant air. Four phases are present in the hot-pressed material (from brightest to darkest contrast): $\mathrm{TaSi}_{2},(\mathrm{Zr}, \mathrm{Ta}) \mathrm{B}_{1.5}, \mathrm{ZrB}_{2}$, and $\mathrm{SiC}$. The exposed sample contains (from brightest to darkest contrast) $(\mathrm{Zr}, \mathrm{Ta}) \mathrm{C}_{\mathbf{x}},(\mathrm{Zr}, \mathrm{Ta}) \mathrm{B}_{\mathrm{x}}, \mathrm{ZrB}_{2}, \mathrm{SiC}$ and porosity.
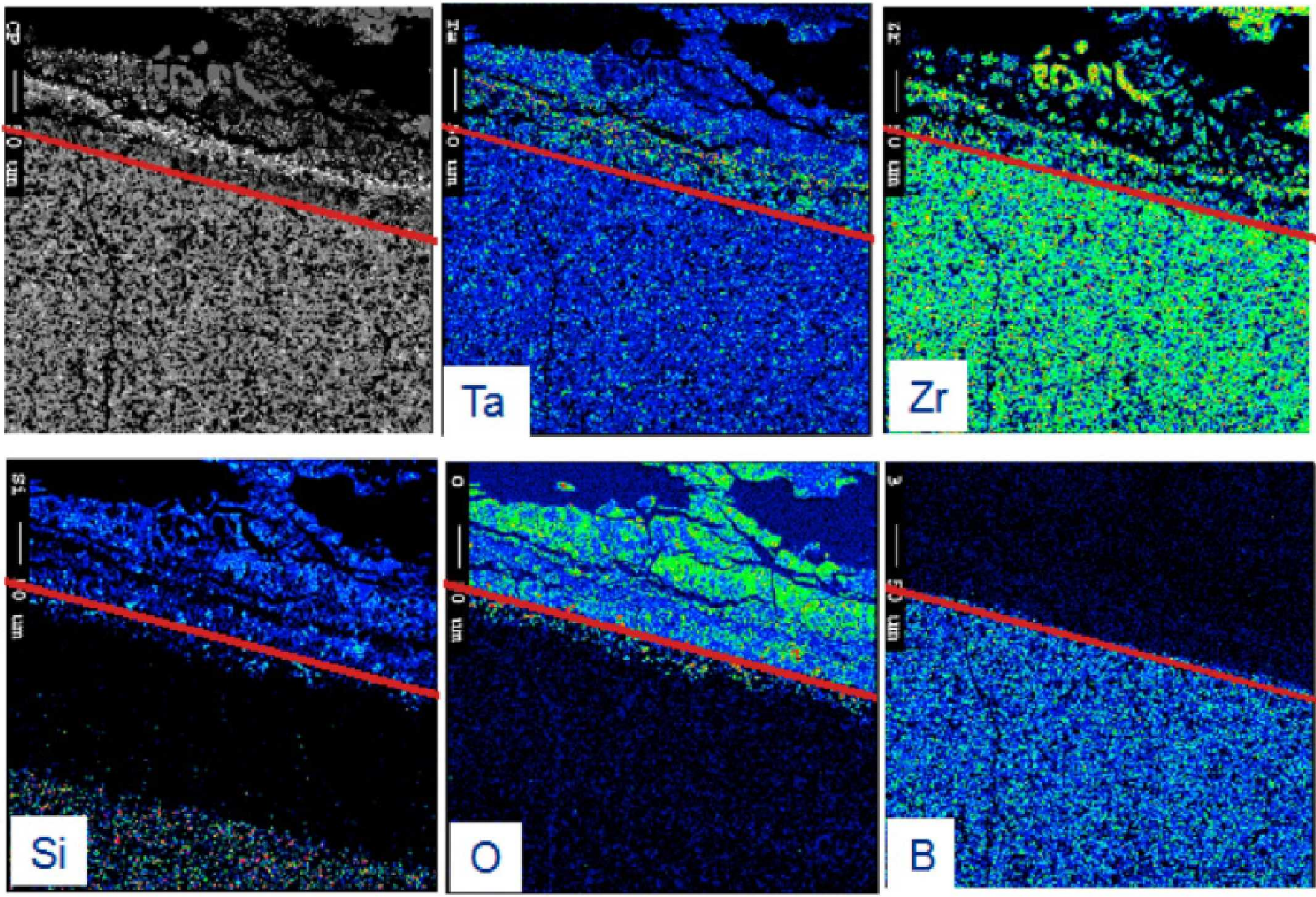

Fig. (7). Backscattered electron image and corresponding WDS dot maps for the substrate/oxide interface of ZSTS20 after oxidation at $1927^{\circ} \mathrm{C}$ for five 10 -minute cycles in stagnant air. The red line corresponds to the approximate location of the $\mathrm{ZrO}_{2} / \mathrm{ZrB}_{2}$ interface as discussed in the text. 

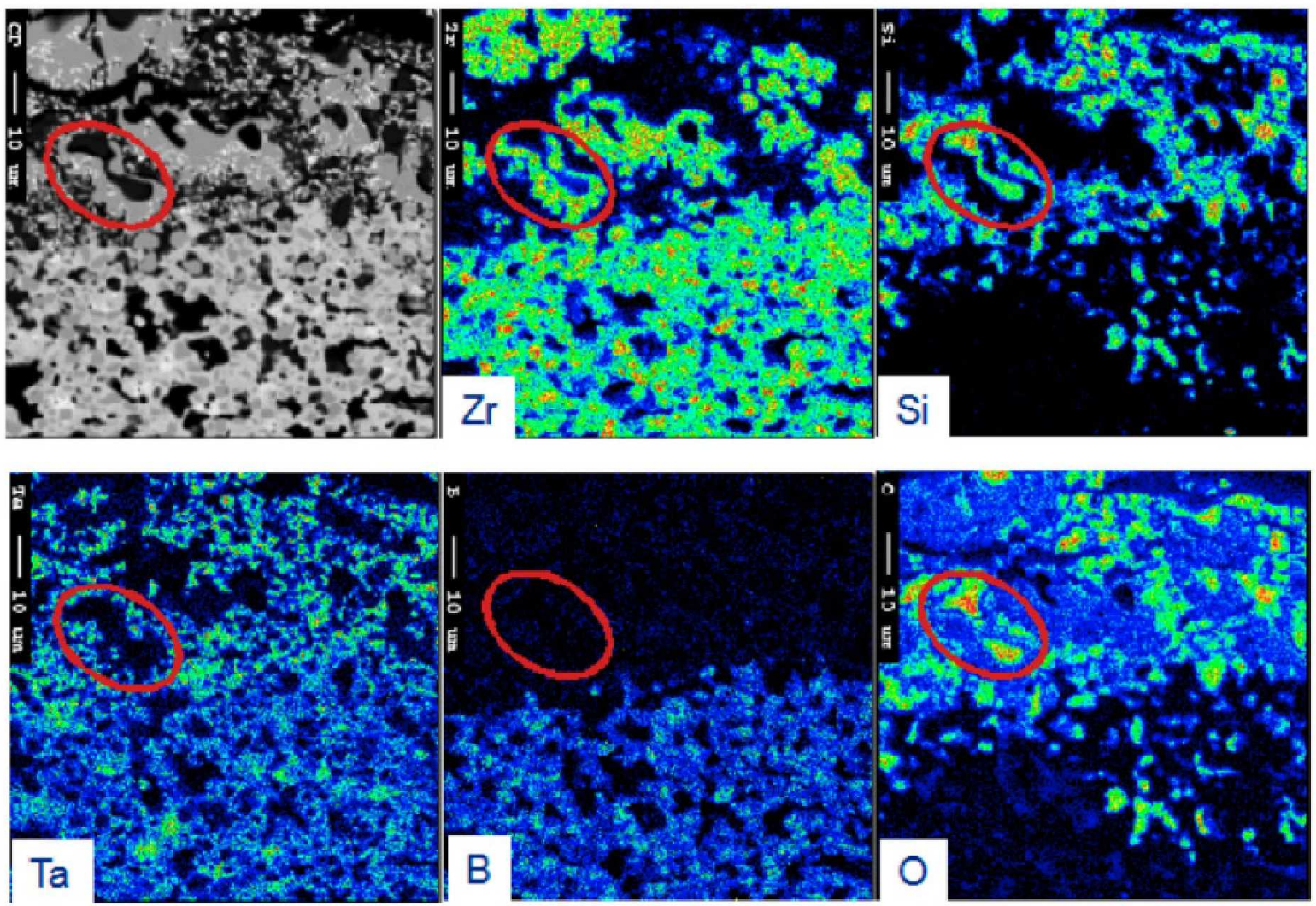

Fig. (8). Backscattered electron image and corresponding WDS dot maps for the substrate/oxide interface of ZSTS20 after oxidation at $1927^{\circ} \mathrm{C}$ for five 10 -minute cycles in stagnant air. The red oval focuses on an area containing $\mathrm{ZrO}_{2}, \mathrm{SiO}_{2}$, and micron-sized, Ta-rich oxyboride phases.

\section{Middle Portion of Attached Scale}

The phases present in this portion of the scale are large columnar $\mathrm{ZrO}_{2}$ grains in $\mathrm{SiO}_{2}$, as shown in Fig. (9). In addition to the finely dispersed $\mathrm{Ta}$ oxyborides, a band of larger grains of $\mathrm{Ta}(\mathrm{C}, \mathrm{B})$ is observed amongst the other oxide phases. Finally, the $\mathrm{ZrO}_{2}$ grains appear to show surface reaction with the surrounding amorphous phase, as shown in Fig. (10).

\section{Outer Surface, Detached Scale}

The phases observed on the outer detached scale and shown in Fig. (11) include $\mathrm{ZrO}_{2}$ found both as large grains and as dendrites, $\mathrm{SiO}_{\mathrm{x}}$ with small amounts of dissolved $\mathrm{Ta}$

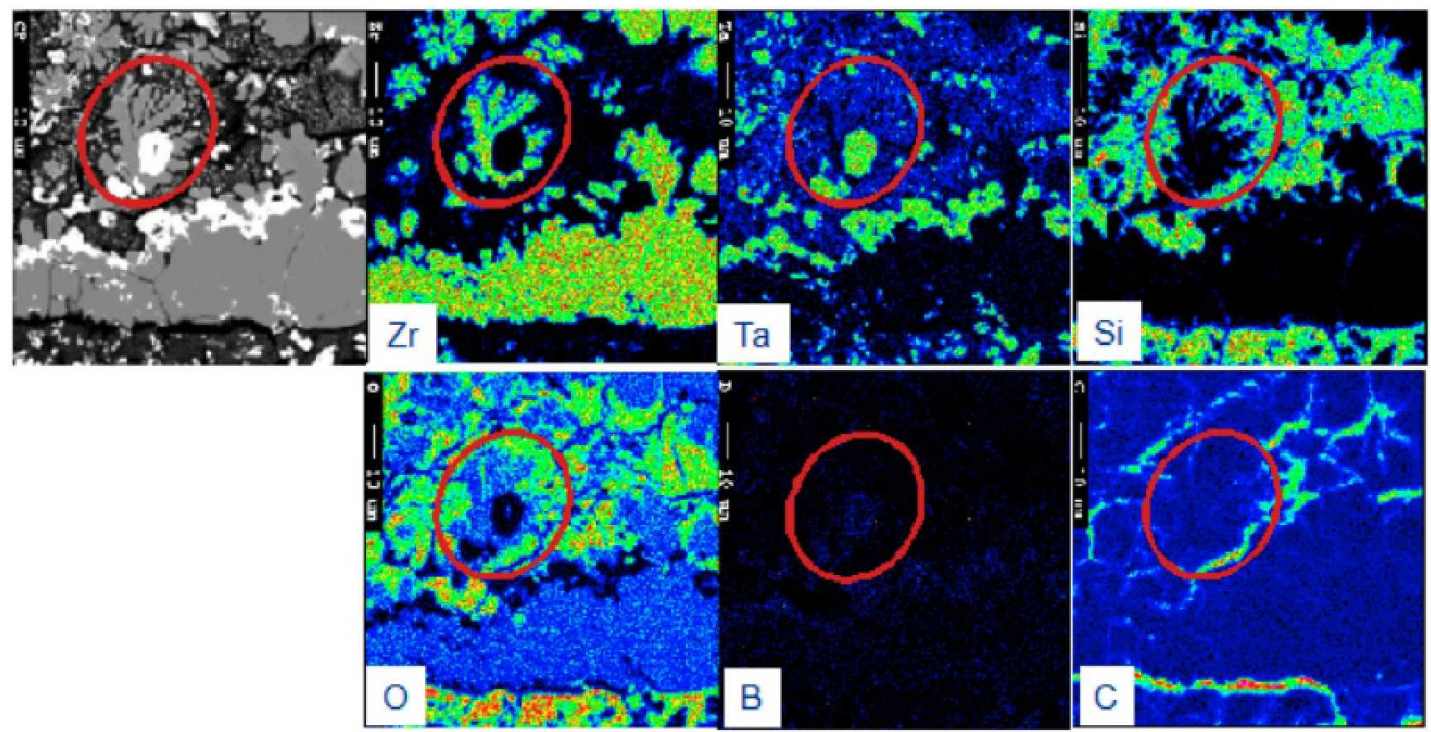

Fig. (9). Backscattered electron image and corresponding WDS dot maps for the middle of the oxide scale formed on ZSTS20 after oxidation at $1927^{\circ} \mathrm{C}$ for five 10 -minute cycles in stagnant air. The red oval focuses on an area containing $\mathrm{Ta}(\mathrm{C}, \mathrm{B})$ (brightest phase). 
and $\mathrm{Zr}$ and $\mathrm{x}=3$, and a $(\mathrm{Zr}, \mathrm{Ta})$ oxide with a cation/anion stoichiometry of $2: 5$ as would be expected for $\mathrm{Ta}_{2} \mathrm{O}_{5}$, however, two thirds of the cations are $\mathrm{Zr}$.

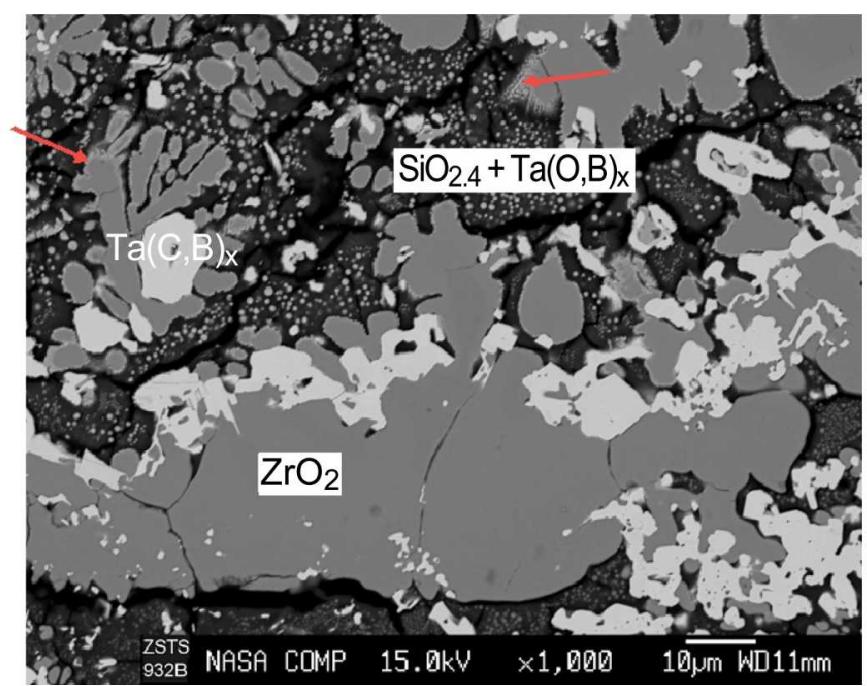

Fig. (10). Backscattered electron image of the middle of the oxide scale formed on ZSTS20 after oxidation at $1927^{\circ} \mathrm{C}$ for five $10-$ minute cycles in stagnant air. Same area as Fig. (9). The red arrows highlight the bright contrast surface layer found on zirconia suggesting Ta-enrichment.

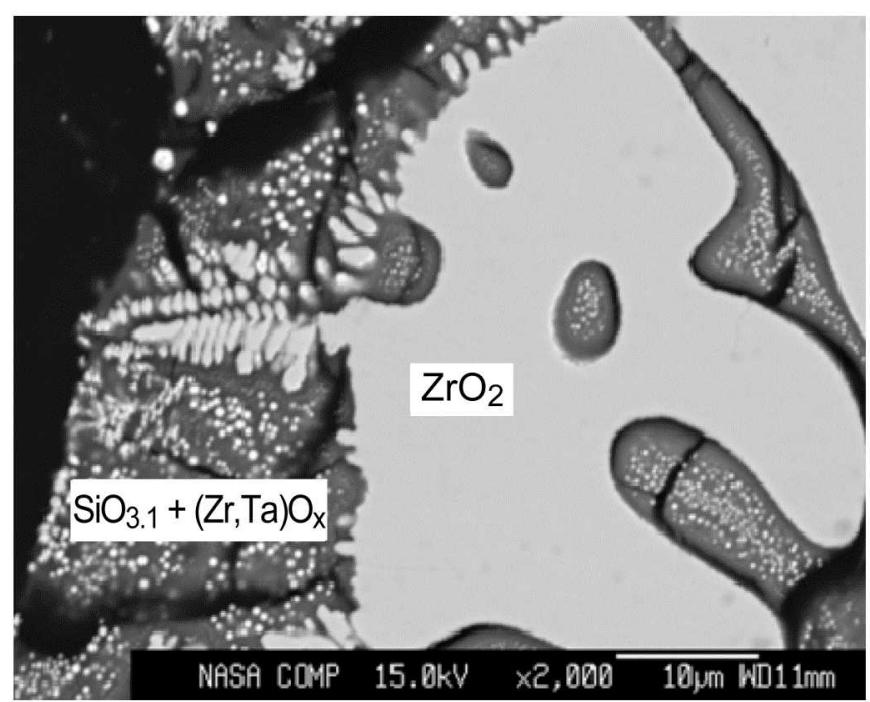

Fig. (11). Backscattered electron image of zirconia dendrites observed on the outer detached oxide scale formed on ZSTS20 after oxidation at $1927^{\circ} \mathrm{C}$ for five 10 -minute cycles in stagnant air

\section{DISCUSSION}

\section{Optimization of $\mathrm{TaSi}_{2}$ Content}

Twenty vol \% addition of $\mathrm{TaSi}_{2}$ to $\mathrm{ZS}$ promoted improved oxidation behavior at $1627^{\circ} \mathrm{C}$. Both the weight change (Fig. 1) and the oxide thickness (Fig. 4) confirm this result. The appearance of the oxide surface indicates glass immiscibility, as shown in Fig. (3). Talmy et al [7-9] attribute similar observations of glass immiscibility to $\mathrm{Ta}$ additions to the system. EDS analysis [10] of the immiscible phases in Fig. (3) were inconclusive. The darkest phase showed EDS consistent with $\mathrm{SiO}_{2}$. The medium contrast phase showed results consistent with $\mathrm{Al}$ and $\mathrm{Mg}$ impurities concentrated in a $\mathrm{SiO}_{2}$-rich phase. In addition, a trace peak attributed to $\mathrm{Ta}$ and or $\mathrm{Zr}$ was also observed [10]. The bright phase had EDS results consistent with $\mathrm{ZrO}_{2}$ and a slight trace of $\mathrm{Ta}$ or $\mathrm{Si}$. The trace of $\mathrm{Ta}$ or $\mathrm{Si}$ could be oxide doping or a sampling volume effect. The sample was unavailable for further microprobe analysis to better characterize the composition of the surface oxide phases since it had been cross-sectioned, mounted and polished for oxide thickness measurements. Thus, while glass immiscibility has been observed, the mechanism for improved oxidation resistance due to Ta additions is still not certain.

The oxidation weight gain of ZSTS5 was similar to ZS (no $\mathrm{TaSi}_{2}$ additions) at $1627^{\circ} \mathrm{C}$. After only ten minutes of oxidation the ZSTS5 scale showed significant amounts of the pink scale observed previously for the ZSTS20 samples (Fig. 2). However, this pink oxide was not able to establish a protective scale at longer times and the glassy appearance of the ZSTS5 after ten cycles was similar in appearance to the ZS material. SEM images of the surface oxide (Fig. 3) show more uniform dispersion of the $\mathrm{ZrO}_{2}$ in a continuous silicarich phase relative to $Z S$, but glass immiscibility of the oxidized ZSTS20 was not observed.

At $1927^{\circ} \mathrm{C}$, it was hoped that the reduction in $\mathrm{TaSi}_{2}$ from 20 to 5 vol \% would eliminate the excess liquid formation attributed to Ta-containing low melting phases, possibly by incorporation of the Ta into the $\mathrm{ZrO}_{2}$. While five vol \% $\mathrm{TaSi}_{2}$ additions to $\mathrm{ZS}$ did reduce the amount of liquid phase relative to ZSTS20, there was still formation of significant amounts of liquid phase indicated by sample distortion, as shown in Fig. (5).

Not only did the reduction in $\mathrm{TaSi}_{2}$ to 5 vol $\%$ fail to provide additional oxidation protection to $\mathrm{ZS}$ at $1627^{\circ} \mathrm{C}$, the reduction was not enough to eliminate liquid phase formation at $1927^{\circ} \mathrm{C}$. Thus, optimization of $\mathrm{TaSi}_{2}$ content is not possible to allow improved oxidation behavior at both 1627 and $1927^{\circ} \mathrm{C}$.

\section{Characterization of ZSTS20 Before and After Oxidation at $1927^{\circ} \mathrm{C}$ in Stagnant Air for 50 Minutes}

\section{Substrate Phases: As Hot-Pressed}

The composition of the hot-pressed material is summarized in Table 3 while images of the material can be seen in Fig. (6). The formation of $(\mathrm{Zr}, \mathrm{Ta}) \mathrm{B}_{1.5}$ indicates that $\mathrm{TaSi}_{2}$ is unstable with respect to $\mathrm{ZrB}_{2}$. The stoichiometry of the new phase $(\mathrm{Zr}, \mathrm{Ta}) \mathrm{B}_{1.5}$ suggests that $\mathrm{Ta}$ is added into the $\mathrm{ZrB}_{2}$ structure without additional boron, resulting in a material with a lower relative boron content. XRD results indicated that the lattice parameters of the $(\mathrm{Zr}, \mathrm{Ta}) \mathrm{B}_{1.5}$ phase were slightly smaller. These results are consistent with substitution of the smaller $\mathrm{Ta}$ atom on the $\mathrm{Zr}$ site and/or incorporation of B vacancies in the ( $\mathrm{Zr}, \mathrm{Ta})$-diboride phase. Table 4 shows the relative thermodynamic stability of a series of compounds important for this material system [5]. It can be seen that silicides are the least stable with $\mathrm{Ta}$ compounds less stable than the corresponding zirconiumbased compounds. These trends are consistent with the 
observed conversion of $\mathrm{TaSi}_{2}$ to $(\mathrm{Zr}, \mathrm{Ta}) \mathrm{B}_{1.5}$ during hotpressing.

Table 4. Free Energy of Formation $\Delta G_{\mathrm{f}} 1927^{\circ} \mathrm{C}(\mathrm{kJ} / \mathrm{mol})$ $M+X_{x}=M X_{x}$ for Compounds of Interest in the ZSTS System [5]. Values for $\mathrm{Ta}_{2} \mathrm{O}_{5}$ are Shown Normalized for $1 \mathrm{Ta}$ and $1 \mathrm{O}_{2}$ for Comparison to Other Phases

\begin{tabular}{|c|c|c|c|}
\hline $\mathrm{TaSi}_{2}$ & -38 & $\mathrm{ZrSi}_{2}$ & -121 \\
\hline $\mathrm{TaC}$ & -140 & $\mathrm{ZrC}$ & -177 \\
\hline $\mathrm{TaB}_{2}$ & -189 & $\mathrm{ZrB}_{2}$ & -277 \\
\hline $\mathrm{TaO}_{2.5}$ & -834 & $\mathrm{ZrO}_{2}$ & -692 \\
\hline $\mathrm{Ta}_{0.8} \mathrm{O}_{2}$ & -451 & & \\
\hline
\end{tabular}

\section{Substrate Phases: After Oxidation at $1927^{\circ} \mathrm{C}$}

After oxidation, no $\mathrm{TaSi}_{2}$ was observed in the matrix. In addition to $\mathrm{ZrB}_{2}, \mathrm{SiC}$, and $(\mathrm{Zr}, \mathrm{Ta}) \mathrm{B}_{1.5}, \mathrm{a}$ new phase $(\mathrm{Ta}, \mathrm{Zr}) \mathrm{C}_{1.4}$ is formed. The amount of the $(\mathrm{Zr}, \mathrm{Ta}) \mathrm{B}_{1.4}$ has increased, the tantalum content in this boride phase has increased and the resulting $B$ stoichiometry has also decreased slightly consistent with more $\mathrm{Ta}$ addition to the structure. This suggests continued reaction between $\mathrm{TaSi}_{2}$ and $\mathrm{ZrB}_{2}$. A possible explanation for additional loss of $\mathrm{TaSi}_{2}$ and the appearance of both voids and the tantalum-rich carbide could be a reaction of the following form:

$\mathrm{TaSi}_{2}+\mathrm{SiC}+1.5 \mathrm{O}_{2}(\mathrm{~g})=\mathrm{TaC}+\mathrm{SiO}(\mathrm{g}), \Delta \mathrm{G}_{\mathrm{rn}}=-79 \mathrm{~kJ} / \mathrm{mol}$

with the free energy data obtained from the FACT database [5]. This reaction is a type of active oxidation in which both $\mathrm{TaSi}_{2}$ and $\mathrm{SiC}$ are consumed forming $\mathrm{TaC}$ as the silicon leaves the system as a vapor species. $\mathrm{TaC}$ is more stable than $\operatorname{SiC}\left(\Delta \mathrm{G}_{\mathrm{f}} 1927^{\circ} \mathrm{C}=-140 \mathrm{~kJ} / \mathrm{mol} v \mathrm{~s}-41 \mathrm{~kJ} / \mathrm{mol}\right)[5]$ making this a likely reaction route.

\section{Oxide Phases Formed: $\mathrm{ZrO}_{2}$}

$\mathrm{ZrO}_{2}$ is observed as large grains tending toward a columnar structure throughout the scale. The amount of $\mathrm{Ta}$ dissolved in the $\mathrm{ZrO}_{2}$ structure increased toward the outer surface of the oxide, but remained low, $1.3 \mathrm{at} \%$ or less. This suggests that incorporation of Ta into the $\mathrm{ZrO}_{2}$ is limited for in situ thermally grown oxides. Higher contents of $\mathrm{Ta}_{2} \mathrm{O}_{5}$ have been incorporated in zirconia by traditional powder or sol gel ceramic processing techniques [18-20]. There are two consequences of this limited solubility of Ta in thermally grown zirconia. First, oxygen ion transport through the zirconia will not be reduced substantially due to oxygen vacancy concentration reduction associated with pentavalent $\mathrm{Ta}$ occupying quadravalent zirconium sites. Ionic conductivity and ion diffusivities are related through the Nernst Einstein equation [21]. Thus, oxygen ionic conductivity measurements as a function of dopant concentration can give information about the changes in oxygen diffusivity. While data for the dependence of ionic conductivity in $\mathrm{Ta}_{2} \mathrm{O}_{5}$-doped $\mathrm{ZrO}_{2}$ are not available in the literature, data obtained for $\mathrm{ZrO}_{2}$ co-doped with $\mathrm{Y}_{2} \mathrm{O}_{3}$ and $\mathrm{Ta}_{2} \mathrm{O}_{5}$ show less than an order of magnitude decrease in ionic conductivity for $2 \mathrm{~mol}^{2} \mathrm{Ta}_{2} \mathrm{O}_{5}$ additions $[22,23]$. Thus, a $\mathrm{Ta}_{2} \mathrm{O}_{5}$ content of about $1 \%$ in $\mathrm{ZrO}_{2}$ is not likely to substantially reduce the oxidation rates of ZS materials. Second, since solubility of $\mathrm{Ta}$ in thermally grown $\mathrm{ZrO}_{2}$ is limited, any excess $\mathrm{Ta}$ is likely to form low melting oxide phases which are detrimental to oxidation resistance at temperatures exceeding their melting point. The formation of zirconia dendrites shown in Fig. (11) is evidence of zirconia incorporation in and precipitation from these low melting phases.

There is additional evidence of zirconia reaction with $\mathrm{Ta}$ in the bright contrasting phases formed around each zirconia grain as seen in Fig. (10). Microprobe was not conducted on these surface reaction phases, so the composition is unknown. One possibility is that this phase is the V-phase, $\mathrm{Ta}_{2} \mathrm{O}_{5}-\mathrm{xZrO}_{2}(\mathrm{x}=5$ to 8$)$. An additional zirconium tantalate phase was observed phase separated in the silica in the outer detached layer of the oxide scale, though this phase has the $2: 5$ stoichiometry of $\mathrm{Ta}_{2} \mathrm{O}_{5}$.

\section{Oxide Phases Formed: $\mathrm{SiO}_{2}$}

$\mathrm{SiO}_{2}$ is observed as the continuous phase that surrounds the columnar zirconia grains as well as any Ta-containing phases. Microprobe results indicate the expected $\mathrm{SiO}_{2}$ oxygen stoichiometry near the oxide/substrate interface. The oxygen stoichiometry deviates moving outward through the oxide scale while correspondingly more Ta is incorporated in the silica. A maximum of 2.5 at $\% \mathrm{Ta}$ is observed in the silica. At the outer surface, small spheroids of phaseseparated zirconium tantalate are observed in the silica as previously mentioned and shown in Fig. (11). The stoichiometric and compositional trends indicate that "pure" silica is formed at the oxide/matrix interface and more complex silicate melts are formed in the outer portion of the oxide as the scale thickens.

\section{Oxide Phases Formed: Ta-Oxides}

$\mathrm{Ta}_{2} \mathrm{O}_{5}$, the thermodynamically stable oxide of $\mathrm{Ta}$ is not observed anywhere in the oxide scale. Near the substrate/oxide interface, small submicron precipitates of Taoxyboride are dispersed in both the $\mathrm{ZrO}_{2}$ and the $\mathrm{SiO}_{2}$ (Fig. 8). The observation that these particles are dispersed in the zirconia supports the limited solubility of $\mathrm{Ta}$ in the $\mathrm{ZrO}_{2}$.

Proceeding outward through the scale, larger $10 \mu \mathrm{m}$ sized particles of $\mathrm{Ta}(\mathrm{C}, \mathrm{B})$ grains are observed in a layered structure (bright phase in Fig. 9). This layer corresponds to the highest concentration of Ta observed in the oxide scale as shown in Fig. (7). The existence of these large non-oxide grains is surprising since they are surrounded by oxide. However, based on the Ellingham diagram calculated using the Fact database [5] shown in Fig. (12), tantalum oxides are the least thermodynamically stable, so that for a limited amount of oxygen, zirconia is expected to form preferentially. A similar phenomenon was observed in which BN remained unoxidized when surrounded by $\mathrm{SiO}_{2}$ due to the relative thermodynamic stabilities of the boria and silica [24].

As discussed above, two zirconium tantalate phases are observed in the outer portions of the scale while more $\mathrm{Ta}$ is observed dissolved in both the zirconia and the silica. These 
more complex tantalates are found in the outer portions of the scale suggesting further $\mathrm{Ta}$ reactions occur at longer exposure times.

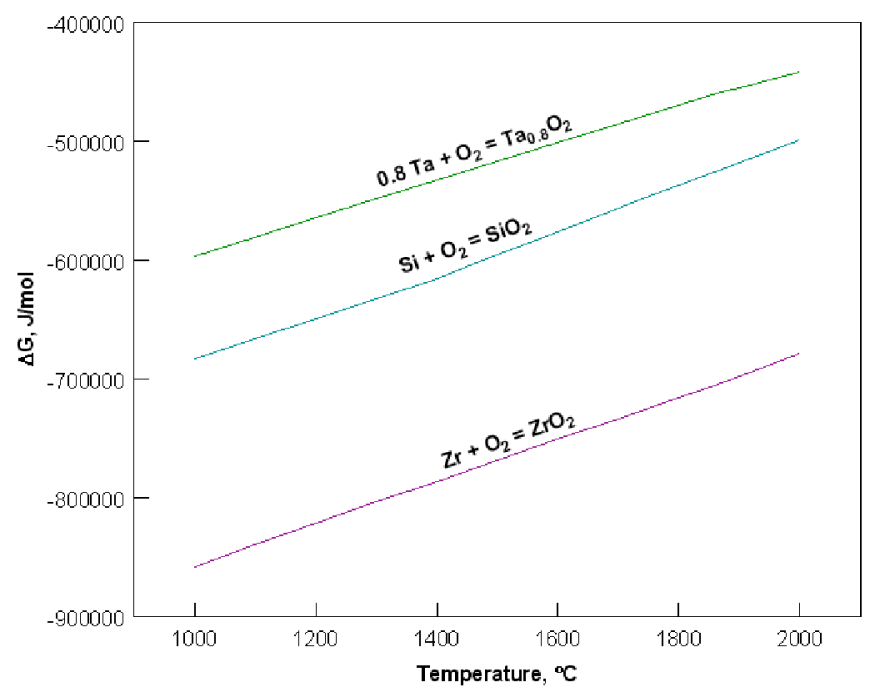

Fig. (12). Ellingham diagram for oxides in the ZSTS system calculated with FACT53 data and FactSage [5].

\section{CONCLUSIONS}

Previous results [10] have shown that additions of $20 \mathrm{v} \%$ $\mathrm{TaSi}_{2}$ to $\mathrm{ZrB}_{2}-20 \mathrm{v} \% \mathrm{SiC}$ resulted in markedly improved oxidation resistance at $1627^{\circ} \mathrm{C}$ in air for 100 minutes. This improved oxidation resistance is likely attributed to Tainduced glass phase immiscibility and resulting lower transport rates of oxygen through the more viscous glasses. However, it has now been demonstrated that addition of the smaller amount of $5 \mathrm{v} \% \mathrm{TaSi}_{2}$ to $\mathrm{ZrB}_{2}-20 \mathrm{v} \% \mathrm{SiC}$ is insufficient to result in glass immiscibility and improved oxidation resistance. $\mathrm{TaSi}_{2}$ additions to $\mathrm{ZrB}_{2}-20 \mathrm{v} \% \mathrm{SiC}$ in both 5 and $20 \mathrm{v} \%$ amounts resulted in extensive liquid phase formation when exposed for 50 minutes in stagnant air at $1927^{\circ} \mathrm{C}$. Extensive microprobe characterization of the $20 \mathrm{v} \%$ $\mathrm{TaSi}_{2}$-containing sample, $1927^{\circ} \mathrm{C}$ exposure, has shown that $\mathrm{TaSi}_{2}$ additions are not suitable for applications at $1927^{\circ} \mathrm{C}$ for a number of reasons. $\mathrm{TaSi}_{2}$ is unstable in the matrix with respect to $\mathrm{ZrB}_{2}$. During oxidation, $\mathrm{TaSi}_{2}$ in the presence of $\mathrm{SiC}$ appears to undergo active oxidation forming $\mathrm{TaC}$ and $\mathrm{SiO}(\mathrm{g})$ leaving voids in the substrate. During oxidation, $\mathrm{Ta}$ is incorporated in the zirconia in amounts of 1.3 at $\%$ or less, suggesting that in-situ doping of the zirconia to decrease oxygen transport rates through the zirconia is limited. During oxidation, Ta also forms oxyboride, silicate, and zirconate phases which result in extensive amounts of liquid phase formation and poor oxidation resistance. Ta-additions to $\mathrm{ZrB}_{2}-20 \mathrm{v} \% \mathrm{SiC}$ are not recommended for ultra-high temperature $\left(>1900^{\circ} \mathrm{C}\right)$ applications.

\section{ACKNOWLEDGEMENTS}

The authors would like to acknowledge Ralph Garlick (GRC, deceased) for the x-ray diffraction results and Jim Nesbitt (GRC) for a careful review of this paper. This work was funded by NASA Next Generation Launch Technology
Program, Airframe Technology Project and the NASA Fundamental Aeronautics Program, Hypersonics Project.

\section{REFERENCES}

[1] W.G. Fahrenholtz, G.E. Hilmas, I.G. Talmy, and J.A. Zaykoski, "Refractory diborides of zirconium and hafnium," J. Am. Ceram. Soc., vol. 90, pp. 1347-1364, May 2007.

[2] J.B. Berkowitz-Mattuck, "High temperature oxidation III. Zirconium and hafnium diborides," J. Electrochem. Soc., vol. 113, pp. 908-914, Sep 1966.

[3] E.V. Clougherty, R.L. Pober, and L. Kaufman, "Synthesis of oxidation resistant metal diboride composites," Trans. Metall. Soc., vol. 242, pp. 1077-1082, June 1968.

[4] X.-H. Zhang, P. Hu, and J.-C. Han, "Structure evolution of $\mathrm{ZrB}_{2}$ SiC during the oxidation in air," J. Mater. Res., vol. 23, pp. 19611972, July 2008.

[5] C.W. Bale, P. Chartrand, S.A. Decterov, G. Eriksson, K. Hack, R. Ben Mahfoud, J. Melançon, A.D. Pelton, and S. Petersen, "FactSage thermochemical software and databases", Calphad J., vol. 62, pp. 189-228, 2002.

[6] X. Zhang, P. Hu, J. Hun, and S. Meng, "Ablation behavior of $\mathrm{ZrB}_{2-}$ $\mathrm{SiC}$ ultra high temperature ceramics under simulated atmospheric re-entry conditions," Comp. Sci. Technol., vol. 68, pp. 1718-1726, 2008.

[7] I.G. Talmy, J.A. Zaykoski, M.M. Opeka, and S. Dallek, "Oxidation of $\mathrm{ZrB}_{2}$ ceramics modified with $\mathrm{SiC}$ and group IV-VI transition metal diborides," in High Temperature Corrosion and Materials Chemistry III, Electrochemical Society Proceedings Volume 200112, M. McNallan, and E. Opila, Eds., Pennington, NJ: The Electrochemical Society, Inc., 2001, pp. 144-158.

[8] I.G. Talmy, J.A. Zaykoski, M.M. Opeka, and A.H. Smith, "Properties of ceramics in the system $\mathrm{ZrB}_{2}-\mathrm{Ta}_{5} \mathrm{Si}_{3}$," J. Mater. Res., vol. 21, pp. 2593-2599, Oct. 2006.

[9] I.G. Talmy, J.A. Zaykoski, and M.M. Opeka, "High-temperature chemistry and oxidation of $\mathrm{ZrB}_{2}$ ceramics containing $\mathrm{SiC}, \mathrm{Si}_{3} \mathrm{~N}_{4}$, $\mathrm{Ta}_{5} \mathrm{Si}_{3}$, and $\mathrm{TaSi}_{2}$," J. Am. Ceram. Soc., vol. 91, pp. 2250-2257, July 2008.

[10] E. Opila, S. Levine, and J. Lorincz, "Oxidation of $\mathrm{ZrB}_{2-}$ and $\mathrm{HfB}_{2}$ based ultra-high temperature ceramics: effect of Ta additions", $J$. Mater. Sci., vol. 39, pp. 5969-5977, 2004.

[11] HSC http://www.outotec.com/pages/Page__35369.aspx?epsla nguage $=\mathrm{EN}(\mathrm{Feb}, 20,2010)$.

[12] T. Ya. Kosolopova, Handbook of High Temperature Compounds: Properties, Production, Applications. NY: Hemisphere Publishing Corp, 1990, pp. 162.

[13] A. Reisman, F. Holtzberg, M. Berkinblit, and M. Berry, "Reactions of the group VB pentoxides with alkali oxides and carbonates III. Thermal and X-Ray phase diagrams of the system $\mathrm{K}_{2} \mathrm{O}$ or $\mathrm{K}_{2} \mathrm{CO}_{3}$ with $\mathrm{Ta}_{2} \mathrm{O}_{5}$," J. Am. Chem. Soc., vol. 78, pp. 4514-4520, Sep. 1956.

[14] B.W. King, J. Schultz, E.A. Durbin, and W.H. Duckworth, "Some properties of tantala systems," Battelle Memorial Institute Report No. BMI-1106, 1956.

[15] Powder Diffraction File, International Centre for Diffraction Data, Swarthmore, Pennsylvania, card no. 42-60.

[16] H.M. Ondik, and H.F. McMurdie, Eds. Phase Diagrams For Zirconium And Zirconia Systems, Westerville, OH: The American Ceramic Society, 1998, p. 144.

[17] S.R. Levine, and E.J. Opila, "Tantalum addition to zirconium diboride for improved oxidation resistance," NASA-TM 2003212483, 2003.

[18] M.M. Abou Sekkina, M.A. Ewaida, E.M. Ibrahim, and A.A. AlAwady, "Investigations of microstructural changes and spectral characteristics of tantala stabilized zirconia refractories," Polym. Degrad. Stab., vol. 19, pp. 273-278, 1987.

[19] M.A. Ewaida, M.M. Abou Sekkina, E.M. Ebrahim, and A.A. AlAdawy, "Novel studies on the thermoelectro-mechanical properties of tantala-doped zirconia refractories," Polym. Degrad. Stab., vol. 21 , pp. 227-235, 1988.

[20] G. Gritzner, C. Puchner, A. Pissenberger, and J. Dusza, "Vanadia, niobia, and tantala doped zirconia," in Ceramics, Charting the Future, p. Vincenzini, Ed. Faenza - Italy: Techna Srl, 1995, pp. 1411-1417.

[21] P. Kofstad, Nonstoichiometry, Diffision, and Electrical Conductivity in Binary Metal Oxides, Wiley-Interscience, New York, 1972. 
[22] M. Caillet, C. Deportes, G. Robert, G. Vallier, and G. Vitter, "Structure et conductivite electrique a haute temperature dans le systeme $\mathrm{ZrO}_{2}-\mathrm{Y}_{2} \mathrm{O}_{3}-\mathrm{Ta}_{2} \mathrm{O}_{5}$," Rev. Int. Hautes. Temper. et Refract., vol. 5, pp. 173-179, 1968.

[23] A.G. Kotlyar, A.D. Neuimin, S.F. Pal'guev, V.N. Strekalovskii, and V.N. Zubankov, "Structure and electrical conductivity in the system $\mathrm{ZrO}_{2}-\mathrm{Y}_{2} \mathrm{O}_{3}-\mathrm{Ta}_{2} \mathrm{O}_{5}$," Inorg. Mater., vol. 6, pp. 281-285, Feb 1970.

[24] B.W. Sheldon, E.Y. Sun, S.R. Nutt, and J.J. Brennan, "Oxidation of BN-coated SiC fibers in ceramic matrix composites," $J$. Am. Ceram. Soc., vol. 79, pp. 539-43, Feb 1996.

(C) Opila et al.; Licensee Bentham Open.

This is an open access article licensed under the terms of the Creative Commons Attribution Non-Commercial License (http: //creativecommons.org/licenses/by$\mathrm{nc} / 3.0 /$ ) which permits unrestricted, non-commercial use, distribution and reproduction in any medium, provided the work is properly cited. 